CHAPTER 6

\title{
Rethinking the Typology from a Biblical Perspective: Paul, Adam, and the Theology of Religions
}

\author{
Philip Whitehead
}

\section{A Pauline Contribution to the Theology of Religions Debate}

The debate in the Theology of Religions from the Christian perspective has predominantly focused on the question of the extent of salvation. This is, with respect to the religious faith of the subject, the underpinning of the familiar threefold typology (Race, 1983) of "exclusivists", "inclusivists", and "pluralists": the extent of salvation excludes those who do not follow the true faith; includes (some/all) others despite their other faith; includes (some/all) others through their other faith. Given the significance of this question for Christian theology at both the theoretical and practical level, this focus is understandable. As Dan Strange has demonstrated in his study of inclusivism within Evangelicalism (2002), the question of who may be saved is particularly urgent for Christians for whom the New Testament has a normative theological role. Strange also highlights that the questions posed by the Theology of Religions intersect not only with the extent and recipients of salvation, but also with many other strands of Christian doctrine, leading to a matrix of responses to pertinent theological questions: whether or not salvation is solus Christus; whether conscious faith in Christ is necessary; whether there is an opportunity to respond to the gospel post mortem; whether few or many or all will be saved (Strange, 2002: 36, 304-331; see also D'Costa, 2009: 7). This intersection of theological questions and doctrinal threads is part of what makes the Theology of Religions a particularly interesting and fecund area of theological study.

Interactions between New Testament scholarship and systematic theological concerns on this issue are, as I shall argue, desirable and mutually beneficial. While different Christian 
traditions have developed different ways of relating scripture to Christian theology, and theologians since Gabler have grown used to distinguishing between "Biblical Studies" and "Dogmatic Theology" (Sandys-Wunsch and Eldredge, 1980), few would want to rule out interaction between the two sub-disciplines entirely. More recently, the value and propriety of theological interpretation of scripture has been affirmed by many (e.g. Treier, 2008) as a way of overcoming this (modern) split between biblical studies and systematic theology.

One criticism it is possible to make about much work in the Theology of Religions, particularly from some pluralist approaches, is that it relies-usually implicitly-on an optimistic, Enlightenment approach to theological anthropology, as shown in claims about God which imply a privileged epistemological position for the pluralist (Surin, 1990: 210), or else collapses into agnosticism in the face of human incapacity to know or speak truly about God (cf. D'Costa, 2009: 10-11, 18). As I shall argue, Pauline theological anthropology-along with the Biblical tradition more widely-is more cautious and pessimistic concerning human capacities. An appreciation of theological anthropology is key for understanding Paul's theology (Jewett, 1971; Moo, 1996: 424), and can also pose challenging questions for the Theology of Religions debate, which may not be obvious when preoccupied with soteriology alone, or when proceeding from a sociological or phenomenological approach to religion.

Why engage with Paul on the issue? Quite apart from the normative status accorded to his writings by large numbers of Christians both historically and now, Paul's theology has been nothing short of formative for the wider Christian theological project and influential upon the Western philosophical tradition. It is hard to disagree with N.T. Wright's appraisal of Paul's significance as an ancient thinker as being comparable to that of Plato or Seneca, in terms of his intellectual stature and influence upon the history of thought (Wright, 2005: 9). Although frequently dichotomous and provocative, Paul is a deep, complex, and nuanced thinker, working to articulate his theology in a religiously plural and politically complex environment. While a simple exercise in proof-texting is to be avoided, a critical but respectful study of Paul brings us into contact with profound theological insights, and holds the possibility of an encounter with "truth" about God and the world (so Bell, 2011: 41; citing Landmesser, 1999: 192-94; cf. Tillich, 1974: 41). Furthermore, an exegesis of Paul which 
does not seek to discern his theological contribution is essentially abandoning the hope of finding an argumentative coherence to his thought, and will quickly become either a truncated, bare historical account, or a rapidly fragmenting eisegesis of agenda-driven "readings". As such, an exegetically responsible and careful study and analysis of Paul's theology is not only desirable in itself, but also has much to contribute to the Theology of Religions. ${ }^{1}$

Objections have been raised against reliance upon Pauline thought by significant voices in the Theology of Religions debate: Paul Knitter, for example, protests that there is too much disagreement between Pauline scholars on what Paul meant to make much use of him, and that a focus on Paul can "drown out" other voices in the New Testament witness (1985: 9294). This concern is misplaced. The recognition that Paul-as Apostle to the Gentiles-is one of the New Testament authors with the most to contribute to the debate is not an invalidation of the other authors; it is the canon and not merely the letters of Paul that has been normative for Christian theology. ${ }^{2}$ Knitter points to Paul's rejection of justification by "good works" and the fact that these are seen as "intrinsic to the experience of salvation" in James and the Synoptics (1985: 94), hoping that we will infer that we may take or leave Paul. Yet the perspective offered by James and the gospel writers on "good works" is never that they are a substitute for faith in the God of Israel, and specifically in Jesus Christ. ${ }^{3}$ Similarly, the

\footnotetext{
${ }^{1}$ I adopt the perspective urged, broadly, by Marshall (2004) and Witherington (2010) that New Testament Theology must attempt a theological synthesis of the diverse and complementary witnesses in the New Testament, but that the way to do so is first to allow each author to speak clearly through a respectful study of the respective texts.

${ }^{2}$ One might point here to the twentieth Article of the Church of England, where it is insisted that the church may not "so expound one place of Scripture, that it be repugnant to another". ${ }^{3}$ Whatever one thinks about the theological relationship between James and Paul, or the Synoptics and Paul, regarding works, it is clear that all affirm the necessity of faith in Christ, even if "faith" carries a different meaning for James as for Paul. Given James' strong affirmation of the Shema (2:19) and the salvific importance of believing the truth (5:19ff.) he
} 
diversity of interpretations of Paul in New Testament scholarship is not a priori grounds for the conclusion that study of Paul may not contribute to a Theology of Religions. As much-if not greater-scholarly diversity may be found in the interpretation and application of Karl Barth, or Vatican II, to the Theology of Religions, without anybody suggesting these sources thereby be ruled out. Another objection, posed by Alan Race (2013:10) is that the Bible (and hence Paul) knows nothing of contemporary religions. The religion of the Corinthian "pagans" ( $\tau \grave{\alpha}$ ह̌ $\theta v \eta)$ spoken of by Paul may no longer exist; nor the imperial cult of Rome. Yet Paul's theological response to the Gentiles and (what we would term) their religions relies remarkably little on their specific details-anything which might be thought to present an "incommensurability" with contemporary world faiths-and is drawn mainly from his Christian gospel and the context and resources of his Jewish background. As I hope to demonstrate in this paper, the category in which he thinks of non-Christians is that of Adam; a category which is inherently universal and which presents no intrinsic obstacle to application to adherents of religions with which Paul had no familiarity. ${ }^{4}$

Adam is the determinative figure for Paul's theology of the human person, and the theological category in which he places those human beings who are not "in Christ". This feature of Paul's anthropology is at once both universal, in that it is a way of talking about all humanity and every individual human, and dichotomous when placed against Christ as two categories or realms, into one-and only one-of which everyone falls. The anthropological challenge to the Theology of Religions can be approached via the question: what difference does being a Christian make? Indeed, for Paul, whose own conversion experience bears directly upon his thought and writing (Kim, 1981), the question is perhaps better phrased as:

makes as poor a witness for pluralism as Paul. On judgment according to works in Paul, see McFadden (2013).

${ }^{4}$ Knitter (1985: 94) also raises, but does not answer, the question of whether Paul's description of human incapability under sin is an ontological state, or something which merely describes first-century Gentiles. It is my hope that this study will demonstrate Paul intends the former. 
What difference does becoming a Christian make? What is involved in the transfer from the realm of Adam to the realm of Christ? Is it an exchange of one set of beliefs, doctrines, sentiments and behaviours for another? Is it a transfer of allegiance from one group to another? Or might it be an altogether deeper matter, one dealing with the very nature of the human being? An analysis of Paul's argument in Romans, and in particular his Adam/Christ language, suggests the latter.

\section{Adam in Romans}

As J.D.G. Dunn has said, the importance of Adam for Paul's theology is often understated, although "Adam is a key figure in Paul's attempt to express his understanding both of Christ and of man" (1980: 101). Adam is mentioned by name in Paul's argument in Romans 5, though his significance extends well beyond that in the letter. One of Paul's key concerns in Romans is to address Jewish/Gentile issues within the church, and Adam is employed as a figure with whom both groups ${ }^{5}$ have equal solidarity (Moo, 1996: 290). In common with Luke in his genealogy of Jesus, and the writer of Jude, Paul undoubtedly took Adam to be a historical figure and the first human being temporally, though his employment of Adam in his theology does not dwell or depend on this. Rather, he employs Adam as a representative figure; even a "mythic" one in the sense of a figure in whom we participate (Bell, 2007: 27, 251). Here, "mythic" is not to be understood as "not true", but to indicate both the transempirical manner in which the figure of Adam is deployed by Paul, and the way in which it betokens a claim about the human being at the very deepest level through narrative. As Hans Frei has pointed out (1974: 42f., 124-126) with the opening chapters of Genesis, what we have with Adam is an ascriptive-rather than a descriptive-narrative which really means what it says, but on its own terms. For Paul, the significance of Adam is not genetic or "scientific",

\footnotetext{
${ }^{5}$ That the category of "Adam" includes Jews in Paul's thought is clear from the appearance of Moses in Romans 5:12-21. Dunn (1988: 284) argues Paul is at pains to demonstrate that "Jews have not escaped the entail of Adam's disobedience by virtue of the law".
} 
but rather in the mysterious way humanity is represented in him and bound, with him, to the power of sin.

It is frequently noted that Paul speaks not of $\alpha \mu \alpha \rho \tau i ́ \alpha$ ("sins") plural, but of $\dot{\alpha} \mu \alpha \rho \tau i ́ \alpha$ ("sin") as characterizing the human condition. Sin is conceived as an ontological state, as something which:

affects not only the sinner's actions and behaviour, but reaches into his being and attacks the centre of his person. In the [sinner's] break with God, an irrevocable offence against the very terms of his existence takes place, to live by and for God ... sin is thus determinative for the human being's whole existence; and the sinner is "ungodly" not only in his evil deeds, rather, he is in a state of being comprehensively far from God and hostile towards God. It is of this state of being a sinner-and not merely of a simple misdemeanour or a failure which can be solved by the person themselves-that Paul speaks (Höfius, 1994: 123, my translation).

This state characterizes both Jew and Gentile, as Paul demonstrates in Romans 1:18-3:20, since all alike are under the power of sin (3:9). This "cosmic" perspective on sin (Gaventer, 2004: 229) relates directly to Paul's use of Adam in Romans.

The idea of Adam as a representative of all humanity is one found in the Jewish tradition (Seifrid, 2007: 629). Ecclesiastes 7:29 (Hebrew) and Hosea 6:7 make reference to Adam as the first or paradigmatic sinner. ${ }^{6}$ The representative motif is developed and elaborated in

\footnotetext{
${ }^{6}$ While Barr (1992) is quite correct that the Genesis account of Adam as found in the Hebrew Bible is not, on its own, so starkly pessimistic as Paul, and that the radicalisation of sin and representative or participative nature of Adam is found more in Hellenistic Jewish texts, this Hellenistic "anthropological pessimism" is clearly a thought world in which Paul operates (Westerholm, 2006) and, though his interpreting the Hebrew Bible in the light of the Christ event, understands Adam as associated with sin, death, and human incapacity. In other words, Paul clearly believes in a "Fall" even if one might not reach this conclusion from the Hebrew Bible alone.
} 
literature from the Second Temple period and after: for example, the pseudepigraphal author of 4 Ezra (7:118, transl. Charlesworth, 1983) laments:

O Adam, what have you done? For though it was you who sinned, the fall was not yours alone, but ours also who are your descendants.

Here the author is reflecting on the enormity of sin in the context of the destruction of the Second Temple, and comes to similar conclusions to Paul regarding the sin of Adam as having radical consequences for humanity after him. ${ }^{7}$ Stephen Westerholm has demonstrated similar radicalisation of the Genesis Adam material to explain a "pessimistic" anthropology in (some) sectarian Judaism of Paul's time (2006: 71ff, 93). Anthony Thiselton also demonstrates that this representative view of Adam is found in some Hellenistic Wisdom texts and Philo (2000: 1282). One can point to the "re-writing" of the Adam and Eve material in Jubilees as reflecting a belief in Adam as the primordial sinner and origin of sin (though in the Noah testament in Jubilees this is seen as radicalised and spread to all humanity via the Watchers story. Cf. Segal, 2007: 34, 57-58). Paul's employment of Adam in his argument in Romans is as a counterpoint to Christ, as also in 1 Corinthians 15:22, 45-49 (Thiselton, 2000: 1281-1283; Dunn, 1973: 127ff.), and is thus more elaborate than those known to us from surviving Second Temple texts. ${ }^{8}$ Paul invests Adam with a deeper significance as the (negative) counterpoint to Christ. ${ }^{9}$ Adam and Christ form one of Paul's antitheses: each

\footnotetext{
${ }^{7}$ Nevertheless, there seems to have been some diversity in the way Adam is interpreted, with the author of 2 Baruch putting forwards the somewhat incompatible idea that "each of us has been the Adam of his own soul" (54:19, transl. Charlesworth, 1983; cf. Davies, 1970: 53). ${ }^{8}$ N. T. Wright argues that there is an established motif of Israel's vocation to be the "true Adam" in Second Temple literature (1992: 262-268), which Paul then presumably applies to Christ as the "true Israel". Whether or not the development of Paul's Christology moved from Adam to Christ directly, or Adam via Israel to Christ, it seems to be the former language he employs most often in his references to Adam.

${ }^{9}$ Fitzmyer, who is loath to admit allusion to Adam outside of Romans 5:12-21, thinks Paul invented the doctrine of incorporation into Adam, arguing it "seems to appear for the first
} 
associated respectively with death, sin, and judgement, and life, freedom, and salvation (Höfius, 2002a: 65-66).

\section{Romans 1:18-23}

The idea of Adam playing a role in Paul's description of human wickedness in Romans 1 is perhaps the most debateable of the Adam allusions in Romans. Morna D. Hooker, among others, has argued there is a "remarkable parallelism" between the language in verses 18-23, and Genesis 1 (Hooker, 1990: 77-78; 1960: 297; Hyldahl, 1956: 285-288). ${ }^{10}$ Dunn also sees an "obviously deliberate echo of the Adam narratives" here (1988: 53), whereby the

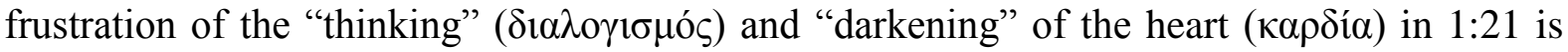
understood to parallel the curse of Adam in Genesis (Dunn, 1998: 84). ${ }^{11}$ The knowledge of

time" in 1 Corinthians 15 (1992: 412). While Paul clearly assigns a deeper-as I shall argue, ontological-significance to Adam than other Second Temple writers, this is clearly building upon an understanding of Genesis he gained from his Jewish background.

${ }^{10}$ Fitzmyer counters that Genesis 1 and 2-3 are separate narratives (though presumably not for pre-Wellhausen Paul) and that alleged echoes of Adam in Romans 1:18-23 are "nonexistent" (1992: 274). However, the use of $\gamma \mathbf{v} \omega \dot{\sigma \kappa} \omega$ in Romans 1:19ff. may be a verbal allusion to the Septuagint of Genesis 3; additionally, allusion and echo is not limited to verbal parallel, but can also encompass semantic domain and concept (cf. Hays, 1989: 20-31, 199n.75). Dunn suggests it is "the description of human aspiration for greater knowledge and a position of high regard which actually results in a decline into disadvantage and a position of low regard" which is modelled on and alludes to Adam (1988: 60).

${ }^{11}$ The use of these terms seems to indicate the totality of the human being, but dwelling particularly on the corruption of the intellectual aspect of the human person by sin; the

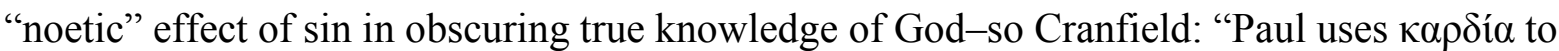
denote a man's inward, hidden self as a thinking, willing and feeling subject" (1975: 118). This ambiguity to human knowledge (Moroney, 1999; see also Gaffin, 1995 on 1 Corinthians 
God in Romans 1:18 is thus one that is available to Adam's "pristine mind" and one in which humanity participates in some manner (Hooker, 1960: 300). However, this participation is also a participation in the frustration of Adam's mind due to sin, with the result that humanity now is at an epistemically disadvantaged position when it comes to knowledge of God (Bell, 1998: 110; see also Young, 2000).

However, not all the details of Romans 1 parallel Adam. In verses 24ff. the Gentiles seem to be in view. For example, Paul's reference to homosexuality and idol-worship is unrelated to the story of Adam (although Wedderburn examines the suggestion idolatry is associated with Adam's fall in Second Temple Jewish thought, he concludes this is unlikely. 1980: 313-319), but very similar to the denouncement of Gentile behaviour found in Wisdom 11-15; if Adam's transgression and condition are in mind in this passage, it is likely mixed with humanity's condition in general: a case of Paul using the concept and semantic range of Genesis' Adam story without precise verbal allusion. The fact that there is this mixing and compounding of the fall of Adam and the fallenness of humanity in Paul's language here (Wedderburn, 1980: 418; Bell, 1998: 24-25) supports the hypothesis that Paul views humanity in solidarity with Adam.

Certainly Paul's indictment of the Gentiles in this passage is universal, and encompasses not only their acts of idolatry, and immorality, but asserts that these derive from a corruption of the mind and heart; that is, an ontological "fallenness" to the whole human being under the power of sin, which he links explicitly to Adam in 5:12.

\section{Romans 5:12-21}

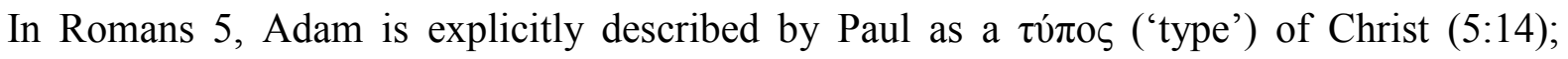
though this comparison is not a strict equivalence, and in fact Adam serves largely as a negative image (Cranfield, 1975: 273; Dunn, 1988: 296-298). My understanding of the

2:6-16) should discourage the appeal to Romans 1:18 as a proof-text for "natural theology" or the a priori validity of non-Christian religious traditions. 
progression of Paul's argument here is as follows: Sin, envisaged as a cosmic power, entered the world through Adam's transgression, and death as a consequence of that, with the result that all of humanity following Adam exist under the power of sin and death: to borrow a phrase from Otfried Höfius' study of Romans 7 (2002b: 104ff.), "in the shadow of Adam". Sin exists before the Law and the establishment of Israel, and is thus a feature of all human existence. Adam is a type of Christ, but the negative image of him: their achievements

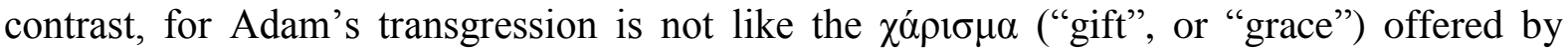
Christ. The result of the one is death and condemnation; that of the other is grace, righteousness, and the covering of many transgressions (Leithart, 2008).

The precise understanding of how Adam's transgression causes sin and death to spread to all is controversial, and has been debated since the time of the early church. ${ }^{12}$ Pelagius insisted people sin by following Adam's example; however, Paul's use of Adam here would scarcely seem to allow that view: why parallel Adam with Christ in this way if there is no especial significance to Adam? Rather, there seems to be a way by which, in Paul's thought, Adam's transgression has an effect on all human beings. Cranfield suggests (1975: 274-281), and may well be right, that what is inherited from Adam is not shared guilt in his discrete transgression, but a sinful nature or disposition, so that all in Adam are under the power and influence of sin, and inevitably commit transgressions themselves (cf. Höfius, 2002a: 82). Thus, it is an ontological condition that is inherited from Adam. I would, however, say that the language and imagery here is that of participation in Adam, just as much as the clearly participatory language used to describe Christ in chapter 6. In some sense human beings are seen to participate in Adam's transgression and its associated consequences, in the same way as Paul considers Christians to participate in Christ's death: they "have been crucified with Christ" (Galatians 2:20, cf. Romans 6:8).

\section{Romans 7:7-13}

\footnotetext{
${ }^{12}$ A helpful summary of patristic views on this is presented in Greer (1995: 382-94). The exegetical issues involved are covered comprehensively in Johnson (1974: 298-316).
} 
Adam also seems to play a role in Paul's argument in Romans 7. There are well-rehearsed

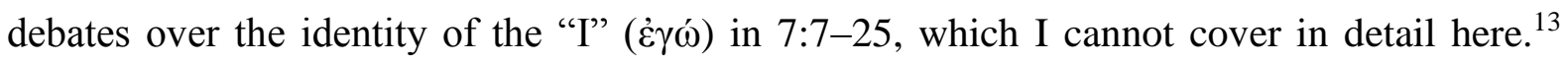
Given Paul's language in the preceding chapter concerning the Christian being "freed from sin and alive to God" (6:22) and of slavery to sin being a thing of the past $(6: 17,20$ uses $\tilde{\eta} \tau \varepsilon$, the imperfect of ciuí, connoting a continual state of slavery to sin in the past; cf. Wallace, 1996: 548) and the state of freedom described in chapter 8 strongly suggests that Paul cannot be describing either his present experience, or the Christian experience in general in 7:7-25. ${ }^{14}$ In verses 7-13, however, Adam is a strong candidate for the "I". The description of the "I" in

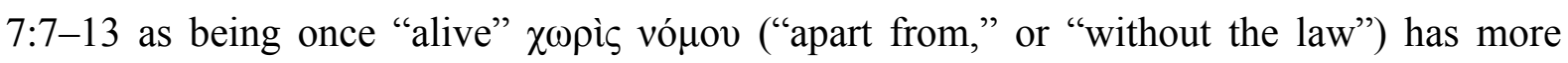
affinity with Adam than with any other individual. ${ }^{15}$ Paul may be alluding deliberately to the

${ }^{13}$ On the history of interpretation, see Wilckens (1978-1982: 2.101-117) and Reasoner (2005: 67-84).

${ }^{14}$ Though the view that Romans 7:7-25 cannot refer to the Christian is sometimes accused of representing an "over-realized eschatology" (Barrett, 1991: 137-144) and thus an unreasonably optimistic view of the Christian experience (Cranfield, 1975: 342, 347), it must be noted both that Romans 8:10-13, 18-23, 34-36 describes a Christian existence involving suffering and death, awaiting eschatological vindication, and thus giving a full expression of Paul's "now-and-not-yet" schema; and that Paul's language in both chapters 7 and 8 seems to be describing theological and ontological realities for the human being in union with Adam or Christ respectively, and not necessarily conscious experience. Even if Paul is primarily describing his pre-Christian experience in 7:7ff. we have to reckon with the lack of troubled conscience he seemed to have felt as a Pharisee (cf. Philippians 3:6).

${ }^{15}$ Schreiner (1998: 361) objects that Adam cannot be meant here as Paul describes a commandment of the Decalogue, which Adam could not have encountered (also Moo, 1996:

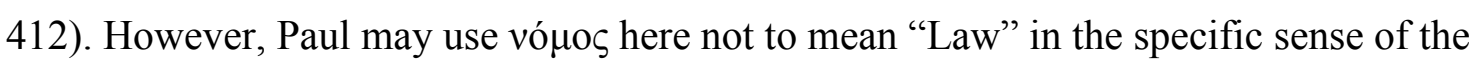
Decalogue or Mitzvot, but in a more general sense of God's commandment-specifically the 
Genesis 3 narrative of Adam's transgression: There was once a time when Adam was without sin, and, having been deceived ( $\dot{\varepsilon} \xi \alpha \pi \alpha \tau \alpha \dot{\omega} \omega),{ }^{16}$ sinned, and "died". For Paul, as we have seen in Romans 5, this is the origin of sin and death in the world, and so, strictly speaking, 7:9 can only refer to Adam. As Ernst Käsemann says of the "I" of 7:7-13, "[t]here is nothing in our passage which does not fit Adam, and everything fits Adam alone" (1980: 196; cf. Wilckens, 1978-1982: 2.79; Sprinkle, 2013: 103).

In 7:14ff. more than Adam-most likely the personified general state of the human being under sin-may be in view, but Adam certainly fits the description of one who was once alive and without the law, but who, through the provocation of the commandment became enslaved to sin, death and the law. It is hard to make sense of the passage if only the Adam of Genesis 2-3 is meant throughout, however, especially given Paul's use of "I" to describe Adam, who he has referred to in the third-person a few paragraphs ago. The depiction of a historical or literary character in the first-person, known as prosopoiia, is a standard feature of GraecoRoman rhetoric, ${ }^{17}$ and could be employed here to stress the identification of Adam with the "I" Paul writes of here, as Ben Witherington has suggested (2012). I suggest that Paul is using the "I" to refer to the experience of humanity in general under sin, who are jointly and severally incorporated into Adam. He is thus describing an ontological state of those who are not united to Christ, rather than an historically contingent condition of first-century "pagans". Sin is, in this passage and for Paul, an enslaving power, and the implications for a theological anthropology of the human being under its power are extensive. Paul's argument in the

Paradise commandment which Adam in fact breaks. Höfius argues persuasively for this (2002b: 129, 133-35).

${ }^{16}$ On balance this is likely to be a direct verbal allusion to Genesis 3:13. The Septuagint of Genesis 3:13 has $\dot{\alpha} \pi \alpha \tau \alpha \dot{\alpha} \omega$, from which $\dot{\varepsilon} \xi \alpha \pi \alpha \tau \alpha \dot{\alpha} \omega$ is derived. The verb $\dot{\varepsilon} \xi \alpha \pi \alpha \tau \alpha \dot{\alpha} \omega$ is rare in the New Testament, occurring only in the Pauline corpus, and explicitly refers to the Genesis 3 narrative in 2 Corinthians 11:3 and 1 Timothy 2:13 (where $\dot{\alpha} \pi \alpha \tau \dot{\alpha} \omega$ is used of Adam and the more intense $\grave{\varepsilon} \xi \alpha \pi \alpha \tau \alpha \dot{\omega} \omega$ of Eve!).

${ }^{17}$ In which Paul was undoubtedly trained, as demonstrated by Stowers (1994). 
preceding two chapters has entailed that the human being is either associated with Adam or Christ. To borrow the phrasing of 1 Corinthians 15, the human being is either "in Adam" ( $\dot{\varepsilon} v$

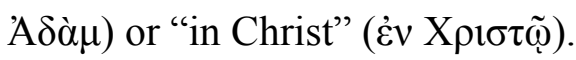

This requires more precision, however. If statements such as "I was once alive apart from the law" strictly speaking apply to Adam alone, how then can the "I" represent humanity in Adam? The difficulty can be resolved if the passage is read in the light of Paul's use of participative language in his Adam-Christ typology. This is recognised in what is often called "Federal headship" in Reformed theology-the idea that Adam's fall involved a participation of the entire human race, with Adam as their representative head-although I argue Paul goes beyond it in asserting an ontological and anthropological reality to the notion of participation in Adam. Here, perhaps the "I" is to be understood as Adamic humanity, with the implication that the participation of the human being in Adam is not only legal, but has some ontological basis; just as union with Christ for the Christian is no "legal fiction" but involves a genuine participation (cf. Romans 6:5-11) so too is the non-Christian united to Adam in sin and death. Thus, it is objectively possible for this "I" to say "I died" in Adam's transgression (7:10). The condition which follows, for all human beings in Adam, is one characterized by bondage to sin and incapacity to know or relate properly to God. Furthermore, this is how Paul thinks of all non-Christians, and so the relevant consideration for him is not the ethics taught by a particular tradition, but a mission-oriented concern that God effects the conversion of non-Christians, transferring them from the realm of Adam to Christ.

\section{Some Theological Implications}

This participative, "mythic" use of Adam in Paul's theology to describe human beings has a number of implications for a Theology of Religions following Paul. If we accept Paul's ideas of union with Adam or Christ, we must see these statements as making a far stronger claim than being merely shorthand labels for religious affiliation. It is my contention that Adam provides the central theological category into which non-Christians fall in Paul's thought. There is much here that is mysterious and requires further study. To say someone is "in 
Adam", or "in Christ" is a claim with a greater ontological significance than we might attach to calling them "non-Christian" or "Christian" in everyday language. Paul really does view the actions and fate of Adam as having direct consequences on the very nature of human beings far removed from him in space and time, in the same way that he views Christians as having really been present in Christ's death and resurrection. An aspect of the human being is therefore deeply bound up with either Adam or Christ. This aspect is clearly a non-material and non- or sub-conscious facet of the human being; what Christian theology has traditionally termed the soul (cf. Bell, 2007). Furthermore, Paul sees this as a genuine dichotomy of belonging to Adam or, and only or, Christ; there is no third option here. His scheme may be summarized fairly as:

Two great figures stand at the entrances to two worlds: Adam stands at the gate of the old world, Jesus at the gate of the new. Adam's first sin inaugurated the old age and brought sin, death, and condemnation. Now in Jesus a new day of righteousness, life and justification has come (Romans 5:12-21). If we are "in Adam," we are part of the old age and under its sway. But if we are "in Christ," we are part of the age to come and can already experience God's life-giving power (Bartholomew and Goheen, 2004: 189).

Paul speaks, too, of conversion meaning a transfer of the human being from the realm of Adam to the realm of Christ. This is, beyond the exchange of beliefs, doctrines and behaviours, the difference that becoming a Christian makes, according to Paul. Conversion involves an ontological change at some level of the human being, and if this is so, we must say that Paul views the Christian as ontologically different to the pre-Christian or the nonChristian. The change is effected by the action of God in transferring the human being from the realm of Adam to the realm of Christ; it cannot be effected by the human subject themselves, who finds themselves in a predicament they cannot solve. ${ }^{18} \mathrm{He}$ or she is now united to and participating in Christ, rather than in Adam. A transfer of being and status has

\footnotetext{
${ }^{18}$ This last phrase is borrowed from Judith Butler (2005: 103) who uses it in a different context to describe the human condition.
} 
taken place, as well as a transfer of religious affiliation. This certainly accounts for Paul's dichotomous language elsewhere concerning Christians and non-Christians, and would support some of the claims made by so-called "exclusivist" theologians. ${ }^{19}$

As Seifrid points out (2007: 692), Paul's use of Adam in Romans also "clarifies Abraham's place". That is, Paul demonstrates that non-Christian Jew and Gentile alike belong to the realm of Adam, and that the real inheritors of Abraham's blessing are thoseboth Jew and Gentile-whom God has united with Christ. ${ }^{20}$ Both Christ and Adam take priority over Abraham (and Moses) here; with the corollary for Christians engaged in interfaith dialogue that it is perhaps not useful to develop a category of the "Abrahamic religions" over against, e.g. Hinduism.

${ }^{19}$ The focus on conversion, however, would add support to a strongly "missionary" approach which does not write off non-Christians, but seeks their conversion to Christ. Chung (2010: 356-357) urges what he calls a "missional perspective" and objects to "exclusivism" when it is "separatist", though he affirms the uniqueness and finality of Christ and refuses to endorse even evangelical "inclusivism" (370-371). This is an example of one of the major faults of the threefold typology, in that few who affirm core "exclusivist" beliefs wish to describe themselves as "exclusivist" as the terminology implies a certain separatism or lack of interest in inter-religious dialogue.

${ }^{20}$ For Paul this does not erase the history of God's dealings with Israel (Romans 9:4-5; 15:4, 8). Paul seems to be working with the idea, found also in the Hebrew Bible, of the holy "remnant" $(\lambda \varepsilon \tilde{\tau} \mu \mu \alpha)$ within (ethnic) Israel $(11: 5,7 b)$ whom he would presumably see as in some way united with Christ, whereas unbelieving/apostate Israel is not (Schreiner shows that Paul's anguish in 9:1-5 can only be explained by his understanding that "many of his [Jewish] contemporaries are unsaved”, 1998: 485; cf. Käsemann, 1980: 301). Paul never states this explicitly, but his identification of Jesus with the God of Israel in his use of the shema formula in 1 Corinthians 8:6 and as having being present with Moses in 1 Corinthians 10:4 leads me to believe his solution to the question of how faithful Israelites who lived before Jesus were saved would be Christological. 
Paul's theological anthropology here poses a strong challenge to the Theology of Religions debate-if he is correctly understood as claiming that becoming a Christian involves an ontological change in the human being; that Christians and non-Christians are distinct at some level ${ }^{21}$-then a Pauline Theology of Religion must give due account of this, and will pose challenging questions for the wider debate. Paul alleges differences between Christians and non-Christians at a deep level of the human person. Furthermore, if being in Adam entails a corruption of the intellect, (true) knowledge of God may in fact be inaccessible outside of the gospel, and so claims about God and reality bound to a non-Christian religion cannot be uncritically affirmed by Christian theologians.

Further biblical-theological study is clearly necessary to answer questions about the epistemological necessity of Christ for salvation, especially when evaluating "inclusivist" perspectives. We see, however, that a study of Paul's theological anthropology suggests the concept of "union with Christ" is at least as significant as the subject's faith in Christ, which undermines the approaches which are solely focused on the subject's belief. If being "in Christ" means more than beliefs, behaviours, and affiliation, is it separable from these, or are these necessary manifestations of a transfer from the realm of Adam to the realm of Christ? I would tentatively suggest Paul's theology implies the latter. In any case, the ontological predicament human beings are said to be in without Christ, exemplified by the category of Adam, suggests that phenomenological approaches to the Theology of Religions are not capable of giving a full account of religious identity and conversion, and nothing short of a theological approach is sufficient for articulating a Christian understanding of those who belong to other faith traditions.

\section{Bibliography}

\footnotetext{
${ }^{21}$ I do not think Paul claims that this is precisely knowable from any epistemological position other than God's; that is, it is not possible for us to say with certainty whether a specific person is genuinely united with Christ.
} 
Barr, J. (1992). The Garden of Eden and the Hope of Immortality. London: SCM Press.

Barrett, C. K. (1991). A Commentary on the Epistle to the Romans. $2^{\text {nd }}$ ed. London: A\&C Black.

Bartholomew, C. G., \& Goheen, M. W. (2004). The Drama of Scripture. Grand Rapids, Mich.: Baker Academic.

Bell, R. H. (2011). "Reading Romans with Arthur Schopenhauer: Some First Steps toward a Theology of Mind". Journal for the Study of Paul and his Letters 1.1: 41-56.

(2007). Deliver Us From Evil: Interpreting the Redemption from the Power of Satan in New Testament Theology. Tübingen: Mohr Siebeck.

(1998). No one seeks for God: an exegetical and theological study of Romans 1.18-3.20. Tübingen: Mohr Siebeck.

Butler, J. (2005). Giving an Account of Oneself. New York, N.Y.: Fordham University Press.

Charlesworth, J. H. (1983). The Old Testament Pseudepigrapha. 1st ed. Garden City, N.Y.: Doubleday.

Chung, S. W. (2010). “Other Religions”. In G. R. McDermott (Ed.), Oxford Handbook of Evangelical Theology. Oxford: Oxford University Press. Pp. 355-370.

Cranfield, C. E. B. (1975). A Critical and Exegetical Commentary on the Epistle to the Romans. Volume I. International Critical Commentary. Edinburgh: T\&T Clark.

D'Costa, G. (2009). Christianity and World Religions: Disputed Questions in the Theology of Religions. Chichester: Wiley-Blackwell.

Davies, W. D. (1970) Paul and Rabbinic Judaism: Some Rabbinic Elements in Pauline Theology. $3^{\text {rd }}$ ed. London. SPCK.

Dunn, J. D. G. (1998). The Theology of Paul the Apostle. Edinburgh: T\&T Clark.

(1980). Christology in the Making: A New Testament Inquiry into the Origins of the Doctrine of the Incarnation. Philadelphia, Penn.: Westminster John Knox Press.

(1988). Romans 1-8. Word Biblical Commentary 38a. Dallas, Tex.: Word Books. 
(1973). "1 Corinthians 15.45 - Last Adam, Life-giving Spirit". In B. Lindars \& S. Smalley (Eds), Christ and Spirit in the New Testament: Studies in Honour of C.F.D Moule. Cambridge: Cambridge University Press. Pp. 127-141.

Fitzmyer, J. A. (1992). Romans: A New Translation with Introduction and Commentary. Anchor Bible Commentary. New York, N.Y.: Doubleday.

Frei, H. W. (1974). The Eclipse of Biblical Narrative: a study in eighteenth and nineteenth century hermeneutics. New Haven, Conn.: Yale University Press.

Gaffin, R. B., Jr. (1995). "Some Epistemological Reflections on 1 Cor 2:6-16". Westminster Theological Journal 57:103-124.

Greer, R. A. (1995). “Sinned We All in Adam's Fall?”. In L. M. White \& O. L. Yarbrough (Eds), The Social World of the First Christians: essays in honor of Wayne A. Meeks.

Minneapolis, Minn.: Augsburg Fortress. Pp. 382-394.

Hays, R. B. (1989). Echoes of Scripture in the Letters of Paul. New Haven, Conn.: Yale University Press.

Höfius, O. (2002a). "Die Adam-Christus-Antithese und das Gesetz". In idem. Paulusstudien II. Tübingen: Mohr Siebeck. Pp. 62-103.

(2002b). "Der Mensch im Schatten Adams. Römer 7,7-25a". In idem. Paulusstudien II. Tübingen: Mohr Siebeck. Pp. 104-154.

(1994). “»Rechtfertigung des Gottlosen« als Thema biblischer Theologie”. In idem. Paulusstudien. 2nd ed. Tübingen: Mohr Siebeck. Pp. 121-147.

Hooker, M. D. (1990). From Adam to Christ: Essays on Paul. Cambridge: Cambridge University Press.

(1960). “Adam in Romans I". New Testament Studies 6: 297-306.

Jewett, R. (1971). Paul's Anthropological Terms: a study of their use in conflict settings. Leiden: Brill.

Johnson, S. L., Jr. (1974). "Romans 5:12-An Exercise in Exegesis and Theology”. In R. N. Longenecker \& R. C. Tenney (Eds), New Dimensions in New Testament Study. Grand Rapids, Mich.: Zondervan. Pp. 298-316.

Käsemann, E. (1980). A Commentary on Romans. Transl. G. W. Bromiley. 4th ed. Grand Rapids, Mich.: Eerdmans. 
Kim, S. (1981). The Origin of Paul's Gospel. Tübingen: Mohr Siebeck.

Knitter, P. F. (1985). No other name? : a critical survey of Christian attitudes toward the world religions. Maryknoll, N.Y.: Orbis Books.

Landmesser, C. (1999). Wahrheit als Grundbegriff neutestamentlicher Wissenschaft. Tübingen: Mohr Siebeck.

Leithart, P. J. (2008). “Adam, Moses, and Jesus: A Reading of Romans 5:12-14”. Calvin Theological Journal 43.2: 257-273.

Marshall, I. H. (2004). Beyond The Bible: Moving from Scripture to Theology. Grand Rapids, Mich.: Baker Academic.

McFadden, K. W. Judgment According to Works in Romans: The Meaning and Function of Divine Judgment in Paul's Most Important Letter. Minneapolis, Minn.: Fortress, 2013.

Moo, D. J. (1996). The Epistle to the Romans. New International Commentary on the New Testament. Grand Rapids, Mich.: Eerdmans.

Moroney, S. K. (1999). The Noetic Effects of Sin. Lanham, Md.: Lexington Books.

Race, A. (2013). Making Sense of Religious Pluralism. London: SPCK.

(1983). Christians and Religious Pluralism: Patterns in the Christian Theology of Religions. London: SCM Press.

Reasoner, M. (2005). Romans in Full Circle: A History of Interpretation. Philadelphia, Penn.: Westminster John Knox Press.

Sandys-Wunsch, J., \& Eldredge, L. (1980). "J. P. Gabler and the Distinction between Biblical and Dogmatic Theology: Translation, Commentary, and Discussion of His Originality". Scottish Journal of Theology 33: 133-158.

Schreiner, T. R. (1998). Romans. Baker Exegetical Commentary on the New Testament. Grand Rapids, Mich.: Baker.

Segal, Michael. The Book of Jubilees: Rewritten Bible, Redaction, Ideology, and Theology. Leiden: Brill, 2007.

Seifrid, M. A. (2007). "Romans". In G. K. Beale \& D. A. Carson (Eds), Commentary on the New Testament Use of the Old Testament. Nottingham: Apollos. Pp. 607-693 
Sprinkle, P. M., Paul and Judaism Revisited: A Study of Divine and Human Agency in Salvation. Downers Grove, Ill.: IVP Academic.

Stowers, S. K. (1994). A Rereading of Romans: Justice, Jews, and Gentiles. New Haven, Conn.: Yale University Press.

Strange, D. (2002). The Possibility of Salvation Among the Unevanglised: An Analysis of Inclusivism in Recent Evangelical Theology. Carlisle: Paternoster.

Surin, K. J.. (1990). "A 'Politics of Speech': Religious Pluralism in the Age of the McDonald's Hamburger”, in Gavin D'Costa (Ed.), Christian Uniqueness Reconsidered: The Myth of a Pluarlistic Theology of Religions. Maryknoll, N.Y.: Orbis Books. Pp.192-212.

Thiselton, A. C. (2000). The First Epistle to the Corinthians: a commentary on the Greek text. New International Greek Testament Commentary. Grand Rapids, Mich.: Eerdmans.

Tillich, P. (1974). Systematic Theology. Vol. 1. Chicago, Ill.: University of Chicago Press. Treier, D. J. (2008). Introducting Theological Intepretation of Scripture: Recovering a Christian Practice. Nottingham: Apollos.

Wallace, D. B. (1996). Greek Grammar Beyond the Basics: An Exegetical Syntax of the New Testament. Grand Rapids, Mich.: Zondervan.

Wedderburn, A. J. M. (1980). “Adam in Paul's Letter to the Romans”. In Elizabeth A. Livingstone (Ed.), Studia Biblica 1978. Volume 3. Sheffield: Sheffield Academic Press. Pp. 413-30.

Westerholm, S. (2006). Paul's Anthropological 'Pessimism' in its Jewish Context. In J. M. G. Barclay \& S. Gathercole (Eds.), Divine and Human Agency in Paul and His Cultural Environment. London: T\&T Clark. Pp. 71-98.

Wilckens, U. (1978-1982). Der Brief an die Römer. Evangelisch-Katholisch Kommentar. 3 Volumes. Neukirchen-Vluyn: Neukirchener Verlag.

Witherington, B., III. (2012). “"But I Would Rather Persuade"...: The Necessity of Understanding Rhetoric for Understanding the Text and Context of the New Testament." Paper presented at the Society of Biblical Literature, Chicago, Ill.

(2010). The Indelible Image: The Theological and Ethical Thought World of the New Testament. Downers Grove, Ill.: IVP Academic.

Wright, N. T. (2005). Paul: Fresh Perspectives. London: SPCK.

(1992). The New Testament and the People of God. London: SPCK. 
Young, R. A. (2000). "The Knowledge of God in Romans 1:18-23: Exegetical and

Theological Reflections.” Journal of the Evangelical Theological Society 43.4: 695-707. 